\title{
TINJAUAN FILOSOFIS TENTANG FUNGSI PENDIDIKAN DALAM HIDUP MANUSIA
}

\author{
Haderani \\ Program Studi Manajemen Pendidikan Islam Fakultas Tarbiyah dan Keguruan \\ Universitas Islam Negeri Antasari Banjarmasin \\ Email: haderani@uin-antasari.ac.id
}

\begin{abstract}
Knowladge is every things important for human. Since born feel this important knowladge. Some factor to get knowladge. Some way is intern factor and extern factor. Need full humanity make human is learning to get knowladge. Education is way the beter than to take knowladge because standart education is well used knowladge for suistainblty for human. Human this name perfect because with the abilty human can make knowladge wise and with norm the everyday life.
\end{abstract}

Key word: education; knowladge; human

\section{ABSTRAK}

Ilmu pengetahuan adalah sesuatu yang esensial dalam kehidupan manusia. Secara naluri sejak lahir manusia sudah mampu merasakan pentingnya ilmu pengetahuan. Beberapa faktor mempengaruhi cara manusia mendapatkan ilmu pengetahuan diantaranya adalah faktor endogen dan faktor eksogen. Pemenuhan kebutuhan hidup membuat manusia belajar untuk mendapatkan ilmu pengetahuan. Pendidikan adalah cara yang paling baik untuk memberikan ilmu pengetahuan karena tolak ukur pendidikan adalah baiknya penggunaan ilmu pengetahuan untuk keberlanjutan hidup manusia. Manusia disebut makhluk sempurna karena dengan kemampuannya manusia dapat menggunakan ilmu pengetahuan secara bijak dan sesuai dengan norma yang berlaku di kehidupan.

Kata kunci: pendidikan; pengetahuan; manusia

\section{Pendahuluan}

Manusia disebut "Homo Sapiens".
Artinya, makhluk yang mempunyai
kemampuan untuk berilmu pengetahuan.
Salah satu insting manusia adalah selalu
cenderung ingin mengetahui segala sesuatu
disekelilingnya, yang belum diketahuinya.
Berawal dari rasa ingin tahu, maka timbulah
ilmu pengetahuan. Dalam hidupnya manusia
digerakan sebagian oleh kebutuhan untuk
mencapai sesuatu, dan sebagian lagi oleh
tanggung jawab sosial dalam masyarakat.
Manusia bukan hanya mempunyai
kemampuan-kemampuan, tetapi juga
mempunyai keterbatasan-keterbatasan, dan

juga tidak hanya mempunyai sifat-sifat yang baik, namun juga mempunyai sifat-sifat yang kurang baik. (Zahara Idris, Lisma Jamal, 1992: 19)

Manusia merupakan mahluk hidup yang lebih sempurna bila dibandingkan dengan mahluk hidup lainnya. Manusia selalu mengalami perkembangan dan perubahan-perubahan baik dari segi Fisiologis maupun psikologis, dimana hal itu dipengaruhi oleh faktor endogen dan faktar eksogen. Ada beberapa teori perkembangan yang menjelaskan masalah ini antara lain :

1. Teori Navitisme; Perkembangan manusia ditentukan oleh faktor Nativus yaitu keturunan yang dibawa oleh 
individu sejak lahir.( Schopenhaur) Menurut teori ini sewaktu individu dilahirkan telah membawa sifat-sifat tertentu, dan sifat-sifat inilah yang menentukan keadaan individu ,sedangkan faktor lingkungan atau pendidikan tidak terpengaruh terhadap perkembangan individu.

2. Teori Emperisme; Teori ini menyatakan bahwa perkembangan seseorang individu akan ditentukan oleh empirinya atau pengalamanpengalamannya ( John Lock ) Dalam teori ini memandang bahwa pendidikan merupakan usaha yang cukup mampu untuk membentuk pribadi individu.

\section{Teori Konvergensi;}

Teori ini penggabungan dari kedua teori diatas yaitu baik pembawaan maupun pengalaman atau lingkungan mempunyai peranan yang penting didalam perkembangan individu (William Stern). Dari bermacam-macam teori perkembangan tersebut diatas. Teori yang dikemukakan William Stern lah merupakan teori yang dapat diterima oleh para ahli pada umumnya. Sehingga teori ini merupakan salah satu hukum perkembangan individu disamping hukum-hukum perkembangan lainnya. Dari uraian diatas dapat dikemukakan bahwa perkembangan individu itu akan ditentukan oleh faktor bawaan (endogen) faktor keadaan maupun lingkungan (eksogen). (M.Noor Syam, 1981: 8- 12)

Ajaran Islam memandang manusia sebagai tubuh, akal dan hati nurani. Potensi dasar manusia yang dikembangkan itu, tidak lain adalah bertuhan dan cenderung kepada kebaikan bersih dari dosa, berilmu pengetahuan serta bebas memilih dan berkreasi. kemampuan kreatif manusia pun berkembang secara bertahap sesuai ukuran tingkat kekuatan dan kelemahan unsur penunjang kreativitas seperti pendengaran, penglihatan serta pikiran. (Ditjen Binbaga Islam, 1984:77-78)

Sebagai khalifah Allah SWT di muka bumi, manusia dituntut mampu mengelola alam dengan beragam ilmu pengetahuan. Oleh karena itu manusia itu sangat membutuhkan pendidikan. Melalui pendidikan manusia dapat mempunyai kemampuan-kemampuan mengatur dan mengontrol serta menentukan dirinya sendiri. Dan dengan pendidikan pula perkembangan kepribadian manusia dapat diarahkan kepada yang lebih baik. Pendidikan bagi kehidupan umat manusia merupakan kebutuhan mutlak yang harus dipenuhi sepanjang hayat. Tanpa pendidikan mustahil suatu kelompok manusia dapat berkembang maju, sejahtera dan bahagia. Pendidikan merupakan wahana penting untuk membangun manusia, dimana pada gilirannya output pendidikan itu akan menjadi sumber daya pembangunan.

Kata pendidikan menurut etimologi berasal darikata dasar didik. Apabila diberi awalan me, menjadi mendidik maka akan membentuk kata kerja yang berarti memelihara dan memberi latihan(ajaran). Sedangkan bila berbentuk kata benda akan menjadi pendidikan yang memiliki arti proses perubahan sikap dan tingkah laku seseorang atau sekelompok orang dalam usaha mendewasakan manusia melalui upaya pengajaran dan latihan. (Purwadarminta, 1982 :250)

Menurut Undang Undang Nomor 20 tahun 2003 Tentang Sistem Pendidikan Nasional bab I pasal 1 ayat 1 menyatakan bahwa pendidikan adalah usaha sadar dan terencana untuk mewujudkan suasana belajar dan proses pembelajaran agar peserta didik secara aktif mengembangkan potensi dirinya untuk memiliki kekuatan spiritual keagamaan, pengendalian diri, kepribadian, kecerdasan, akhlak mulia, serta keterampilan 
yang diperlukan dirinya, masyarakat, bangsa dan Negara.

Ki Hajar Dewantara dalam kongres Taman Siswa pada tahun 1930, menyebutkan bahwa pendidikan umumnya berarti daya dan upaya untuk memajukan tumbuhnya budi pekerti

( kekuatan bathin, karakter), pikiran (intelek) dan tubuh anak. Dalam taman siswa tidak boleh dipisah-pisahkan bagian-bagian itu agar dapat mewujudkan kesempurnaan hidup, kehidupan dan penghidupan anak-anak yang kita didik selaras dengan dunianya. ( Fuad Ihsan; 5 ).

Menurut IKIP Semarang, mengemukakan bahwa pendidikan bermakna; pendidikan adalah aktivitas dan usaha manusia untuk meningkatkan kepribadiannya dengan jalan membina potensi-potensi pribadinya, yaitu rohani (piker, karsa, rasa, cipta dan budi nurani) dan jasmani (pancaindera serta keterampilan-keterampilan). Pendidikan juga berarti lembaga yang bertanggung jawab menetapkan cita-cita (tujuan) pendidikan, isi, sistem dan organisasi pendidikan. Lembaga ini meliputi keluarga, sekolah dan masyarakat. Pendidikan berarti pula hasil atau prestasi yang dicapai oleh perkembangan manusia dan usaha lembega lembaga tersebut dalam mencapai tujuannya. (Tim dosen IKIP semarang, 1990: 7)

\section{A. Manusia Sebagai Makhluk Pendidikan}

Dengan kekuasan Allah manusia diciptakan sebagai makhluk yang paling istimewa dan sempurna dari pada makhluk Allah yang lain. Yang membedakan manusia dengan makhluk lain ialah akal budinya,dengan akalnya manusia bisa membedakan mana yang bermanfaat dan mana yang tidak bermanfaat, sehingga derajat manusia mengungguli derajat makhluk yang lain. Dengan akal budinya manusia menemukan berbagai cara untuk melindungi diri terhadap pengaruh lingkungan yang merugikan. Dengan akalnya pula manusia bisa menemukan penemuan-penemuan baru. Bermacammacam ilmu dipelajari, mulai dari perjalanan hidupnya sendiri, lingkungannya, hingga keberadaan alam semesta, semua diamati dan diteliti secara seksama dan sistimatis. Dengan penelitiannya manusia menemukan ilmu pengetahuan dan teknologi yang bisa mengantarkan manusia kepada kehidupan yang lebih mudah dari sebelumnya.

Manusia adalah makhluk yang paling sempurna diantara mahkluk yang lain ciptaan Allah SWT. Salah satu kelebihan yang di miliki oleh manusia ialah manusia diberi akal pikiran dan nafsu yang tidak dimiliki oleh malaikat, jin dan binatang. Dengan akal inilah diharapkan manusia bisa menggelola bumi ini dengan baik. Untuk melakukan tugas yang berat tersebut maka manusia membutuhkan ilmu pengetahuan, hal inilah yang menyebabkan manusia menjadi objek pendidikan, atau mahluk yang membutuhkan pendidikan.

Manusia adalah mahluk yang bisa di didik dan diajar. Untuk meningkatkan kualitas hidup, manusia memerlukan pendidikan, baik pendidikan yang formal, informal maupun nonformal. Pendidikan merupakan bagian penting dari kehidupan manusia yang sekaligus membedakan manusia dengan makhluk hidup lainnya. "Hewan" juga belajar, tetapi lebih ditentukan oleh instinknya, sedangkan manusia belajar berarti merupakan rangkaian kegiatan menuju pendewasaan guna menuju kehidupan yang lebih berarti. Anak-anak menerima pendidikan dari orang tuanya dan manakala anak-anak ini sudah dewasa dan berkeluarga, mereka akan mendidik anak-anaknya. Begitu juga di 
sekolah dan perguruan tinggi, para siswa dan mahasiswa diajar oleh guru dan dosen. Pendidikan pada manusia dimulai semenjak manusia itu dilahirkan kedunia

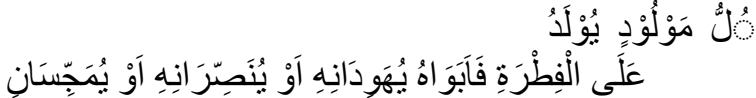

$$
\begin{aligned}
& \text { Artinya: "Setiap anak yang }
\end{aligned}
$$
dilahirkan ke dunia itu dalam keadaan suci. Hanya kedua orang tuanyalah yang membuat anak itu menjadi Yahudi, Nasrani atau Majusi". (HR. Muslim).

Dari hadits atas dapat dipahami bahwa manusia di lahirkan ke dunia ini pertama kalinya tidak mengetahui apa-apa. Menurut teori empirisme manusia bukan baik dan bukan juga jahat semenjak lahir. Dia adalah tabularasa, putih seperti kertas kosong yang belum ditulisi, maka pendidikanlah yang memegang peranan membentuk pribadinya. Kita tahu bahwa manusia terdiri dari unsur biologis dan fsikologis, maka sudah barang tentu pendidikan harus berpijak pada pertimbangan tersebut sehingga pada akhirnya didapat hasil perkembangan yang optimal. (Zahara Idris, Lisma Jamal, 1992: 5-6)

Dari itu sudah seyogyanya pendidikan haruslah mampu mengarahkan dan mengoptimalkan potensi tersebut kearah yang posotif dan meminimalisasi perkembangan negativitas perilaku sebagai efek dari perkembangan manusia yang salah.

Dari potensi-potensi dasar tersebut juga menunjukkan pada kita akan pentingnya pendidikan untuk mengembangkan dan mengolah sampai di mana titik optimal itu dapat capai. Apalagi kita saksikan kondisi manusia pada waktu dilahirkan di dunia ini, mereka dalam keadaan yang sangat lemah, yang secara tidak langsung membutuhkan pertolongan dari kedua orangtuanya. Dengan demikian, pendidikan merupakan faktor yang sangat menentukan kepribadian manusia, potensi jasmaniah dan rohaniah tidak secara otomatis tumbuh dan berkembang dengan sendirinya, tetapi membutuhkan adanya bimbingan, arahan, dan pendidikan.

Mendidik adalah upaya yang dilakukan untuk menumbuhkan, mengembangkan dan menyuburkan, atau lebih tepat "mengkondisikan" sifat-sifat dasar (fithrah) seorang anak yang ada sejak awal penciptaannya agar dapat tumbuh subur dan berkembang dengan baik. Jika tidak, maka fithrah yang ada dalam diri seseorang akan terkontaminasi oleh "kumankuman" kehidupan itu sendiri.

\section{B. Fungsi Pendidikan Dalam Kehidupan Manusia}

Manusia memiliki sejumlah kemampuan yang dapat dikembangkan melalui pendiddikan dan pengalaman. Pendidikan dan pengalaman itu terjadi karena interaksi manusia dengan lingkungannya, khususnya pada tiga lingkungan utama pendidikan yakni keluarga, sekolah dan masyarakat. fungsi pendidikan adalah membantu peserta didik dalam berinteraksi dengan berbagai lingkungan sekitarnya (fisik, sosial dan budaya), utamanya berbagai sumber daya pendidikan yang tersedia, agar dapat dicapai tujuan pendidikan yang optimal. Untuk itu proses pendidikan harus berfungsi untuk mengajarkan tingkah laku umum dan untuk mempersiapkan individu untuk perananperanan tertentu. Sehubungan dengan fungsi ini pendidikan bertugas untuk mengajarkan berbagai macam pengetahuan, keterampilan dan keahlian dalam rangka mempersiapkan anak untuk pekerjaan-pekerjaan tertentu.(Umar Tirtaraharja, La sula, 2000: 164-165). Secara umum pendidikan berfungsi sebagai alat pengembangan pribadi, pengembangan warga Negara, 
pemgembangan kebudayaan, dan pengembangan bangsa ( Fuad Ihsan, 1995; 11)

Dalam undang-undang Sisdiknas No.20 Tahun 2003 Bab II Pasal 3 dikatakan bahwa pendidikan nasional berfungsi mengembangkan kemampuan dan membentuk watak serta peradaban bangsa yang bermartabat dalam rangka mencerdaskan kehidupan bangsa, bertujuan untuk berkembangnya potensi peserta didik agar menjadi manusia yang beriman dan bertakwa kepada Tuhan Yang Maha Esa, berahlak mulia, sehat, berilmu, cakap, kreatif, mandiri, dan menjadi warga negara yang demokratis serta bertanggung jawab.( UU Sisdiknas, 2007 : h. 5 )

Pasal ini menggambarkan bahwa yang harus dikembangkan dalam diri peserta didik adalah potensi-potensi yang dimilikinya, bukan berarti menjejali dengan ilmu pengetahuan semata tanpa mempertimbangkan potensi-potensinya dalam hidup dan penghidupan selaku manusia yang mempunyai keinginan, nafsu, akal dan naluri kemanusiannya. Atau dengan kata lain "mengembangkan berbagai potensi kemanusiaan (memanusiakan manusia), mengembangkan berbagai keterampilan hidup, mengembangkan kepribadian, transfer kebudayaan dari suatu generasi ke generasi berikutnya, dan mempersiapkan anak untuk dapat melaksanakan tugas hidup dan memenuhi berbagai kebutuhan hidupnya sendiri

Selanjutnya dikatakan disitu "dan membentuk watak", hal ini mengandung arti bahwa pendidikan yang dilakukan dapat membentuk watak, sikap, karakter individu yang berada pada lingkungan masyarakatnya, yang cenderung bersifat positif dan tidak bertentangan tatanan tabiat, watak, karakter manusia lainnya. Kemudian dikatakan "serta peradaban bangsa yang bermartabat dalam rangka mencerdaskan kehidupan bangsa”. Peradaban bangsa yang bermartabat dengan kata lain suatu peradaban yang memiliki nilai-nilai luhur suatu bangsa yang sarat dengan nilai-moral bangsanya sendiri. Peradaban suatu bangsa akan diwarnai oleh kemajuan pendidikan dan teknologinya, bagaimana pola hidup orang-orang yang sudah maju dalam pendidikannya, bagaimana pola hidup manusia yang sudah modern sebagai pembentukan dari kemajuan teknologi, semua itu semakin mewarnai budaya suatu bangsa. Oleh karena itu peradaban bangsa yang bermartabat cenderung menitik beratkan pada dasar ideologi suatu bangsa itu, dan dalam kehidupan bangsa Indonesia yang dimaksud dengan bangsa yang bermartabat adalah bangsa yang meletakan ideologi hidupnya adalah nilai-moral Agama Islam sebagai sumber nilai-moral yang mutlak sifatnya bagi seorang muslim yang baik. Selanjutnya dikatakan "dalam rangka mencerdaskan kehidupan bangsa" Mencerdaskan kehidupan bangsa disini memiliki arti meningkatkan tarap pendidikan rakyat agar tidak ada lagi yang buta hurup dan buta aksara pada tatanan penduduk bangsa Indonesia ini.

Semua perbuatan atau usaha dari generasi tua untuk mengalihkan pengetahuannya, pengalamannya, kecakapan serta keterampilannya kepada generasi muda, sebagai usaha untuk menyiapkan mereka agar dapat memenuhi fungsi hidupnya, baik jasmaniah maupun rohaniah dinamakan Pendidikan. Pendidikan sebenarnya sudah dimulai sejak adanya makhluk yang bernama manusia, yang berarti bahwa pendidikan itu berkembang dan berperoses bersama sama dengan proses perkembangan hidup dan kehidupan manusia itu sendiri. Pada zaman primitif, perkembangan manusia itu dalam taraf sangat sederhana, maka pendidikan pada masa itu hanya semata mata sebagai 
pewarisan budaya dari nenek moyang saja. Seperti misalnya pada masyarakat petani, atau nelayan, mereka sudah merasa puas, bilamana telah mengajarkan kepada anaknya, cara cara bercocok tanam, menangkap ikan atau berburu. Tetapi dengan adanya kemajuan zaman, kemajuan kebudayaan, kemajuan iptek, maka pendidikan seperti tersebut diatas masih belum cukup, bahkan masih sangat jauh dari cukup. Adapun faktor penyebabnya adalah karena pendidikan itu bukan sekedar pewarisan nilai-nilai budaya bangsa dari satu generasi ke genarasi berikutnya, namun pendidikan juga suatu cara untuk mengembangkan pribadi dan social anak. Agar dengan demikian anak dapat menyesuaikan diri dengan lingkungannya dan juga dapat memenuhi kebutuhan hidupnya yang semakin komplek dan beraneka ragam. Itulah sebabnya maka pendidikan itu selalu mengalami perkembangan dan pembaharuan dari masa ke masa, baik dalam bentuk maupun caranya, yang dilaksanakan dalam lembaga pendidikan.

Fungsi dan tugas pendidikan sebagai alat untuk mengembangkan kepribadian, memanusiakan manusia, mengembangkan berbagai potensi kemanusiaan, mengembangkan berbagai keterampilan hidup, mempersiapkan anak untuk dapat melaksanakan tugas hidup dan memenuhi berbagai kebutuhan hidupnya sendiri, mengantarkan anak pada kehidupan yang baik. Kehidupan masa depan anak pada masyarakat tradisional umum tidak jauh berbeda dengan kehidupan orang tuanya. Pada masyarakat tersebut, orang tua mengajar pengetahuan dan keterampilan yang diperlukan untuk hidup; orang tua pula yang melatih dan memberi petunjuk tentang berbagai aspek kehidupan, sampai anak menjadi dewasa dan berdiri sendiri. Tetapi pada masyarakat modern di mana industrialisasi semakin berkembang dan memerlukan spesialisasi, maka pendidikan yang semula menjadi tanggung jawab keluarga itu kini sebagian besar diambil alih oleh sekolah dan lembaga-lembaga sosial lainnya. Pada tingkat yang paling permulaan fungsi ibu sebagai sudah diambil alih oleh pendidikan prasekolah. Pada tingkat spesialisasi yang rumit, pendidikan keterampilan sudah tidak berada pada ayah lagi, sebab sudah diambil alih oleh sekolahsekolah dan perguruan tinggi. Bahkan fungsi pembentukan watak dan sikap mental pada masyarakat modern berangsur-angsur diambil alih oleh sekolah dan organisasi sosial lainnya seperti perkumpulan pemuda dan pramuka, lembaga-lembaga keagamaan, media massa, dan sebagainya.

Keluarga

merupakan pengelompokan primer yang terdiri dari sejumlah kecil orang karena hubungan sedarah. Keluarga dapat berbentuk inti maupun keluarga yang diperluas . Pada umumnya jenis kedualah yang banyak ditemui dalam masyarakat Indonesia. Meskipun ibu merupakan anggota keluarga yang mula-mula paling berpengaruh terhadap tumbuh kembang anak, namun pada akhirnya seluruh anggota keluarga itu ikut berinteraksi dengan anak.

Di samping faktor iklim sosial itu, faktor-faktor lain dalam keluarga itu ikut pula mempengaruhi tumbuh kembangnya anak, seperti kebudayaan, tingkat kemakmuran, keadaan perumahannya, dan sebagainya. Dengan kata lain, tumbuh kembang anak dipengaruhi oleh keseluruhan situasi dan kondisi keluarga. Pendidikan keluarga merupakan pengalaman pertama pada masa kanak kanak, menjamin kehidupan emosionil anak, dan menanamkan dasar pendidikan moral, serta memberikan dasar pendidikan sosial,

Selanjutnya sekolah merupakan sarana yang secara sengaja dirancang untuk 
melaksanakan pendidikan. Seperti telah dikemukakan bahwa karena kemajuan zaman, keluarga tidak mungkin lagi memenuhi seluruh kebutuhan dan aspirasi generasi muda terhadap iptek. Semakin maju suatu masyarakat semakin penting peranan sekolah dalam mempersiapkan generasi muda sebelum masuk dalam proses pembangunan masyarakat itu. Fungsi pendidikan di sekolah adalah melatih kemampuan kemampuan akademis Anak (Biar Pintar). Dengan melatih serta mengasah kemampuan menghafal, menganalisa, memecahkan masalah, logika, dan lain sebagainya maka diharapkan seseorang akan memiliki kemampuan akademis yang baik. Orang yang tidak sekolah biasanya tidak memiliki kemampuan akademis yang baik sehingga dapat dibedakan dengan orang yang bersekolah. Kehidupan yang ada di masa depan tidaklah semudah dan seindah saat ini karena dibutuhkan perjuangan dan kerja keras serta banyak ilmu pengetahuan. Menggembleng dan memperkuat mental, fisik dan disiplin dengan mengharuskan seorang siswa atau mahasiswa datang dan pulang sesuai dengan aturan yang berlaku maka secara tidak langsung dapat meningkatkan kedisiplinan seseorang. Dengan begitu padatnya jadwal sekolah yang memaksa seorang siswa untuk belajar secara terus-menerus akan menguatkan mental dan fisik seseorang menjadi lebih baik.

Tanggung jawab seorang anak adalah belajar di mana orangtua atau wali yang memberi nafkah. Seorang anak yang menjalankan tugas dan kewajibannya dengan baik, dengan bersekolah yang rajin akan membuat bangga orang tua, guru, saudara, famili, dan lain-lain. Membangun jiwa sosial dan jaringan pertemanan, banyaknya teman yang bersekolah bersama akan memperluas hubungan sosial seorang siswa. Tidak menutup kemungkinan di masa depan akan membentuk jaringan bisnis dengan sesama teman di mana di antara sesamanya sudah saling kenal dan percaya. Dengan memiliki teman maka kebutuhan sosial yang merupakan kebutuhan dasar manusia dapat terpenuhi dengan baik.

Sekolah sebagai sarana mengembangkan diri dan berkreativitas seorang siswa dapat mengikuti berbagai program ekstrakurikuler sebagai pelengkap kegiatan akademis belajar mengajar agar dapat mengembangkan bakat dan minat dalam diri seseorang. Semakin banyak memiliki keahlian dan daya kreativitas maka akan semakin baik pula kualitas seseorang. Peranan lembaga pendidikan adalah Sebagai pranata sosial bagi kelangsungan hidup dan perkembangan masyarakat melalui upaya sosialisasi, sehingga warga masyarakat memiliki kemampuan dan ciri ciri pribadi sebagaimana yang diharapkan, Sekolah sebagai pusat pendidikan formal lahir dan berkembang dari pemikiran efisiensi dan efektivitas didalam pemberian pendidikan kepada warga masyarakat, disamping lingkungan keluarga dan masyarakat sebagai lembaga pendidikan informal dan non formal. Sekolah mempunyai kewajiban fungsional terhadap kelangsungan dan perkembangan hidup masyarakat, yaitu dengan jalan penyiapan dan pembinaan warga masyakat, sehingga memiliki kemampuan dan pribadi yan diharapkan, Fungsi sekolah untuk seoptimal mungkin membelajarkan anak asuhnya yang tak terbatas pada dinding kelas, tetapi juga dari sumber-sumber belajar di lingkungan masyarakatnya, dan Sebagai agen pembaharuan.

Dari sisi lain, sekolah juga menerima banyak kritik atas berbagai kelemahan dan kekurangannya, Oleh karena itu, kajian ini terutama diarahkan kepada pencarian berbagai upaya yang dapat 
dilakukan untuk meningkatkan peranan dan fungsi sekolah. Sekolah harus diupayakan sedemikian rupa agar mencerminkan suatu masyarakat Indonesia di masa depan itu, sehingga peserta didik memperoleh peluang yang optimal dalam menyiapkan diri untuk melaksanakan peran itu. Oleh karena itu, sekolah seharusnya menjadi pusat pendidikan untuk menyiapkan manusia Indonesia sebagai individu, warga masyarakat, warga negara dan warga dunia di masa depan. (Umar Tirtarahardja, La Sula, 1998: 173).

Masyarakat akan dapat berfungsi dengan sebaik-baiknya jika setiap individu belajar berbagai hal, baik pola-pola tingkah laku umum maupun peranan yang berbedabeda. Untuk itu proses pendidikan harus berfungsi mengajarkan tingkah laku umum dan untuk mempersiapkan individu untuk peranan-peranan tertentu. Disamping itu pula fungsi pendidikan masyarakat adalah untuk mengembangkan kehidupan sosial anak meliputi Social understanding, social skill, social attitude, rasa kemanusiaan, kebersamaan, persaudaraan dan saling tolong menolong. Masyarakat sebagai penyelenggara pendidikan, baik dilembagakan maupun yang tidak dilembagakan, baik langsung maupun tidak langsung, ikut mempunyai peranan dan fungsi edukatif. Dalam masyarakat tersedia berbagai sumber belajar. Dengan kata lain, manusia berusaha mendidik dirinya sendiri dengan memanfaatkan sumber-sumber belajar yang tersedia di masyarakatnya dalam bekerja, bergaul, dan sebagainya.(Umar Tirtarahardja, La Sula, 1998: 165)

\section{Kesimpulan}

Manusia adalah makhluk yang mempunyai kemampuan untuk berilmu pengetahuan. Dalam hidupnya manusia digerakan sebagian oleh kebutuhan untuk mencapai sesuatu, dan sebagian lagi oleh tanggung jawab sosial dalam masyarakat. Manusia bukan hanya mempunyai kemampuan-kemampuan, tetapi juga mempunyai keterbatasan-keterbatasan, dan juga tidak hanya mempunyai sifat-sifat yang baik, namun juga mempunyai sifat-sifat yang kurang baik. Manusia selalu mengalami perkembangan dan perubahanperubahan baik dari segi fisiologis maupun psikologis, dimana hal itu dipengaruhi oleh faktor endogen dan faktar eksogen

Manusia adalah makhluk yang paling sempurna, salah satu kelebihan yang di miliki oleh manusia ialah manusia diberi akal pikiran dan nafsu yang tidak dimiliki oleh malaikat, jin dan binatang. Dengan akal inilah diharapkan manusia bisa menggelola bumi ini dengan baik. Untuk melakukan tugas yang berat tersebut maka manusia membutuhkan ilmu pengetahuan, hal inilah yang menyebabkan manusia menjadi objek pendidikan. Dengan pendidikan akal manusia bisa membedakan mana yang bermanfaat dan mana yang tidak bermanfaat, sehingga derajat manusia mengungguli derajat makhluk yang lain. Dengan memfungsikan akal budi manusia menemukan berbagai cara untuk melindungi diri terhadap pengaruh lingkungan yang merugikan serta bisa menemukan penemuan-penemuan baru.

Manusia itu seperti kertas putih, maka pendidikanlah yang memegang peranan membentuk pribadinya. Manusia memiliki sejumlah kemampuan yang dapat dikembangkan melalui pendidikan dan pengalaman. Pendidikan dan pengalaman itu terjadi karena interaksi manusia dengan lingkungannya, khususnya pada tiga lingkungan utama pendidikan yakni keluarga, sekolah dan masyarakat.

$$
\text { Fungsi pendidikan adalah }
$$
membantu peserta didik dalam berinteraksi 
dengan berbagai lingkungan sekitarnya (fisik, sosial dan budaya). Secara umum fungsi pendidikan adalah upaya mengembangkan berbagai potensi kemanusiaan (memanusiakan manusia), Transfer kebudayaan dari suatu generasi ke generasi berikutnya, Mengembangkan berbagai keterampilan hidup, Mengembangkan kepribadian, dan Mempersiapkan anak untuk dapat melaksanakan tugas hidup dan memenuhi berbagai kebutuhan hidupnya sendiri

Pendidikan Nasional berfungsi mengembangkan kemampuan dan membentuk watak serta peradaban bangsa yang bermartabat dalam rangka mencerdaskan kehidupan bangsa, bertujuan untuk berkembangnya peserta didik agar menjadi manusia yang beriman dan bertakwa kepada Tuhan Yang Maha Esa, berakhlak mulia, sehat, berilmu, cakap, kreatif, mandiri, dan menjadi warga Negara yang demokratis serta bertanggung jawab. Secara umum pendidikan berfungsi sebagai alat pengembangan pribadi, pengembangan warga Negara, pemgembangan kebudayaan, dan pengembangan bangsa.

Pendidikan keluarga merupakan pengalaman pertama pada masa kanak kanak, menjamin kehidupan emosionil anak, dan menanamkan dasar pendidikan moral, serta memberikan dasar pendidikan social. Dan sekolah sebagai sarana mengembangkan diri dan berkreativitas seorang siswa dapat mengembangkan bakat dan minat dalam diri seseorang. Peranan lembaga pendidikan adalah Sebagai pranata sosial bagi kelangsungan hidup dan perkembangan masyarakat melalui upaya sosialisasi, sehingga warga masyarakat memiliki kemampuan dan ciri ciri pribadi sebagaimana yang diharapkan. Selanjutnya fungsi pendidikan masyarakat adalah untuk mengembangkan kehidupan sosial anak meliputi Social understanding, social skill, social attitude, rasa kemanusiaan, kebersamaan, persaudaraan dan saling tolong menolong.

\section{DAFTAR PUSTAKA}

Ditjen Bimbaga Islam. Filsafat Pedidikan Islam, Dep. Agama, Jakarta, 1984

Ihsan, Fuad. Dasar-dasar Kependidikan Komponen, $M K D K$, Penerbit Rineka Cipta, Jakarta 2001.

Idris, Zahara, Jamal,Lisma. Pengantar Pendidikan, Gramedia Wadiasarana Indonesia, Jakarta,1992

Undang-Undang Nomor 20 tahun 2003 tentang Sistem Pendidikan Nasional \& Undang-Undang Nomor 14 tahun 2005 tentang Guru dan Dosen, Visimedia, Jakarta, 2007

Purwadarminta, Kamus Besar Bahasa Indonesia, balai pustaka, Jakarta, 1982

Tirtaraharja,Umar. La Sula, Pengantar Pendidikan, Reneka Cipta, Jakarta, 2000: 